\title{
Pembuatan Scout Learning Berbasis Multimedia Berupa Aplikasi Simulasi Penunjang Ekstrakurikuler Kepramukaan Kalangan Sekolah Dasar Di Jawa Barat
}

\author{
Andri Sahata Sitanggang ${ }^{\# 1}$ \\ \# Sistem informasi, Universistas Komputer Indonesia \\ Jl. Dipatiukur No 112-116 Bandung \\ ${ }^{1}$ sahataandris@gmail.com
}

\begin{abstract}
Scouting is the organization that constitute media to cultivate students greetings gain potentialspiritually, intellectually, physically and mentality in order for students to have personality and noble character, has a high national spirit, creating a mindset that in sightful, as well as making students have arole in helping the community minded patriotism and was candidate for leader of the nation and the state. The existence of interactive innovation with information technology support then scouting can be increased number of student involvement to follow thw scouting extracurricular.

Based on the results of previous studies where the designs system making scout learning proposed uses the approach structured already made, so this research continue to produce a product scout learning based multimedia.Products or the system resulting capable of make a big difference for children primary school in interest to follow ekstrakuriler scouting.

Products made using methods development in prototype by testing betha alpha and an application so as to be as feasible as needed .The scouts learning this dynamic visually oriented, the merger animation, video and sound, an image that is interesting, that provides sandi-sandi simulation, knowledge scouting pramuka and video equipment .
\end{abstract}

Key word: Scout, Learing, animasi, video..

\begin{abstract}
Abstrak
Kepramukaan merupakan salah satu organisasi yang merupakan media untuk membina para siswa dalam memperoleh potensi-potensi secara spritual, intelektual, mentalitas dan fisik agar para siswa memiliki kepribadian dan akhlak mulia, memiliki semangat kebangsaan yang tinggi, menciptakan pola pikir yang berwawasan luas, serta menjadikan siswa memilki peran yang tinggal dalam membantu masyarakat yang berjiwa patriotisme dan menjadi calon pemimpin bangsa dan negara. Adanya inovasi interaktif dengan dukungan teknologi informasi maka kepramukaan dapat ditingkatkan jumlah keterlibatan siswa untuk mengikuti ekstrakurikuler kepramukaan.

Berdasarkan hasil penelitian sebelumnya dimana rancangan sistem pembuatan aplikasi pembejaan kepramukaan yang diusulkan menggunakan metode pendekatan terstruktur sudah dibuat, maka penelitian ini berlanjut untuk menghasilkan suatu produk scout learning berbasis multimedia. Produk atau sistem yang dihasilkan mampu memberikan pengaruh yang besar bagi anak sekolah dasar dalam minat untuk mengikuti ekstrakuriler kepramukaan.

Produk yang dibuat menggunakan metode pengembangannya prototype dengan pengujian secara alfa dan beta dengan memberikan kuisioner sehingga menjadi sebuah aplikasi menjadi layak pakai sesuai kebutuhan. Pembuatan pembelajaran kepramukaan ini berorientasi secara visual yang dinamis, penggabungan animasi, video dan suara, gambar yang menarik, yang menyediakan simulasi sandi-sandi, perlengkapan pramuka serta video pengetahuan kepramukaan.
\end{abstract}




\section{PENDAhaluan}

$\mathbf{M}$ enurut Darma \& Ananda[2], Aplikasi memiliki pengertian "suatu perangkat yang dibuat oleh seseorang/kelompok dalam membantu mengertjakan tugas-tugas kebutuhan manusia, misalnya aplikasi pengolah data seperti Microsoft Word, Microsoft ExceL". Pada kenyataannya bahwa aplikasi memiliki fungsi untuk membantu manusia dalam memenuhi kebutuhan hidup sehari-hari, apapun itu kebutuhannnya seperti alat bantu pekerjaan, hiburan dan lainnya. Sehingga Aplikasi menjadi salah satu tolak ukur dalam menghasilkan fungsi yang berperan penting dalam masyarakat. Aplikasi menjadi jawaban ketika perkembagan teknologi dalam masyarakat berkembang, sehingga tidak menutup kemungkin banyak kegiatan yang dapat dibantu oleh adanya aplikasi. Banyak kegiatan atau aktivitas dalam masyarakat yang didukung oleh aplikasi contohnya seperti pendidikan, kemudahan informasi yang diperoleh dengan adanya aplikasi sangat membantu sekali seperti aplikasi e-book dan aplikasi e-learning yang lainnya.

Berkembangnya suatu teknologi memberikan satu tatanan perubahan dalam masyarakat, beraneka ragam kebutuhan, dan kemudahan teknologi melalui aplikasi menjawab semua permasalahan yang ada dalam masyarakat. Sehingga diperlukan perubahan yang melibatkan teknologi dalam mempertahankan suatu komunitas ataupun kelompok dalam masyarakat.

Kegiatan kepramukaan saat ini menjadi sangat jarang kita temui, padahal sebelumnya bahwa kegiatan kepramukaan adalah bagian utama dari pendidikan yang ada di Sekolah Dasar dimana semangat dan antusias siswa masih sangat besar. Tetapi dengan berkembangnya jaman, perubahan terjadi dikarenakan banyaknya kegiatan ektrakurikuler yang dianggap lebih menarik dibandingkan dengan pramuka. Banyak hal yang terjadi dalam masyarakat dalam menghadapi masalah-masalah yang terjadi seperti intoleran, berita hoak, kejahatan dunia narkoba, kenakalan remaja dalam organisasi geng motor. Hal tersebut dikarenakan tergoresnya nilai-nilai kepramukaan khususnya siswa-siswa dasar yang merupakan calon generasi muda. Maka dari itu ,seperti yang tertuang dalam Raimuna Nasional XI 2017 yang berisi Gerakan pendidikan yang bertujuan untuk yang mempunyai tujuan bahwa kepramukaan membentuk kepribadian seseorang berdasarkan nilai keimanan dan ketaqwaan, berakhlak, memiliki jiwa patriotisme, taat terhadap aturan dan perundang-undangan yang berlaku mempertahankkan nilai-nilai luhur negara, serta memiliki jiwa sebagai pemimpin dalam membangun Negara serta menjunjung tinggi nilai Pancasila. Dari hal tersebutlah maka adanya inovasi pembelajaran yang membantu menumbuhkan rasa minat siswa dasar untuk mempelajari dan mendapatkan pengetahuan dari kegiatan kepramukaan yang dapat mengatasi permasalahan dalam masyarakat, sehingga generasi muda dapat diandalkan dan mempunyai pola pikir dan moral, nilai kebangsaan yang baik.

Tujuan penelitian ini adalah menghasilkan inovasi pengajaran melalui aplikasi scout learning berbasis multimedia dalam mendukung kegiatan kepramukaan siswa sekolah dasar dengan menerapkan interaksi yang dinamis dalam menumbuhkan pengetahuan kepramukaan untuk semua kalangan sisw. Sehingga para siswa juga mudah dalam menerapkan kegiatan kepramukaan dengan aplikasi yang dbuat

\subsection{Multimedia}

\section{KAJIAN PUSTAKA}

Menjelaskan beberapa teori yang berkaitan dengan multimedia antara lain pengertian multimedia, unsur multimedia dan peranan multimedia dalam pembelajaran.

\subsubsection{Pengertian Multimedia}

Menurut Darma \& Ananda[2] Multimedia, "Sebuah bentuk dari perubahan data dari hasil manipulasi semua bentuk informasi yang terdiri dari kata-kata, simbol, video, musik, angka dan tulisan tangan melalui media komputer sebagai hasil pengolahan kedalam bentuk digital".

Menurut Hofstetter[3] dalam bukunya Multimedia LiteracycMultimedia adalah "suatu kegiatan yang menggunakan media atau fasilitas komputer dalam mengolah atau memanipulasi teks,simbol,grafik.gambar,audio, dan video sehingga yang menggunakan multimedia dapat berinteraksi, membuat manipulasi dan berkomunikasi secara langsung". 
Multimedia adalah sebuah alat atau perangkat yang mengkombinasikan gabungan dari berbagai jenis media lain, misalnya penggabungan audio dan visual. Dengan media seperti ini, hampir setiap orang menjadi lebih mudah untuk menerima sebuah informasi

\subsubsection{Unsur Multimedia}

Unsur yang terdapat dalam multimedia ini sesuai dengan yang telah dipaparkan melalui buku multmedia Literac.

a. Suara merupakan "Multimedia dapat berupa bunyi atau radio. Salah satu visual yang dapat diingat oleh manusia sehingga mempunyai peran sangat penting dalam membuat multimedia. Bunyi atauu suara dapat diperoleh dengan hasil pengolahan melalui perangkat/aplikasi yang mendukung perekaman. Dan hasilnya dapat berupa wav, mp3.,midi,dan voc

b. Animasi adalah kumpulan-kumpulan gambar yang secara dinamis bergerak sesuai dengan waktu yang ditentukan, hasil rekayasa gambar yang bergerak secara bergantian. Salah satu pendukung dalam multimedia yang sering kali disukai oleh anak-anak kecil bahkan untuk usia remaja.

c. Video adalah "salah satu media yang juga digemari oleh banyak orang. Kebanyakan orang dapat memahami isi cerita atau masalah dengan menggunakan video. Jadi video adalah bentuk visualiasi yang memilki durasi waktu tertentu sehingga membuat gambar menjadi lebih nyata dan hidup"

d. Grafik adalah "sebuah ilustasi dalam sebuah media yaitu media cetak, lukisan atau gambar dan huruf yang menjadikan komputer sebagai perantara dalam pengolahan data. Hasil olahan data dapat divisualisasikan menggunakan berbagai macam grafik dalam membantu manusia khususnya dalam pembuatan laporan"

e. Text adalah "bentuk media statis yang paling mudah untuk dipahami oleh manusia. Bentuk teks adalah media penyampaian informasi yang sangat umum untuk digunakan. Penggunaan teks biasanya untuk melengkapi dari keutuhan suatu multimedia artinya dengan teks juga membantu dalam menyampaikan isi, maksud dan tujuan".

2.1.3. Peranan Mulitmedia dalam Pembelajaran

Dalam metode pembejaran saat ini hal yang paling merangsang daya ingat seseorang adalah dengan menggabungkan semua unsur visualisasi dari berbagai media. Sehingga memudahkan penyampai informasi kepada penerima informasi.

\subsection{Pengertian Kepramukaan}

Menurut Dahlan [1], "kepramukaan adalah proses kegiatan yang memilki tujuan dalam pendewasaan karakter yang mempunyai bentuk kegiatan yang menyenangkan,menarik. Mempunyai tujuan yang terarah, serta praktis diimplementasikan dialam terbuka dengan prinsip dasar kepramukan dan metode kepramukaan sehingga menghasilkan pembentukan watak seseorang".

Menurut Sunardi[4] pada buku Boyman Ragam Latih Pramuka, "Proses yang terdiri dari kegiatankegiatan yang berlandaskan permainan yang dapat menyenangkan baik orang dewasa dan anak-anak, dengan menerapkan nilai keterampilan, kesehatan,kebahagiaan, dan berjiwa sosial terhadap orang lain yang membutuhkan."

Sifat Kepramukaan (berdasarkan AD\&ART) menyatakan bahwa kepramukaan mempunyai tiga sifat menurut Sunardi[4] yaitu:

a. "Gerakan Pramuka"

Sebuah organisasi yang memilki keanggotaan yang mempunyai dan menanamkan sifat sukarela, mandiri, tidak ada perbedaan ras, agama dan golongan"

b.Tidak memiliki unsur politik tetapi lebih menjunjung nilai luhur bangsa"

c. "Adanya kebebasan dalam memeluk agama dan keyakinannya masing-maing. Tidak ada perbedaan. Saling menghormati dan menghargai kepada setiap pemeluk agama."

Berdasarkan AD \& ART Gerakan Pramuka, Pasal 5 bahwa"Gerakan Pramuka berfungsi sebagai wadah untuk mencapai tujuan Pramuka melalui Pengembangan pramuka, Permainan yang berorientasi pada pendidikan, Pengabdian masyarakat dan orang tua, Pendidikan dan pelatihan pramuka

2.3. Aplikasi.

Beberapa aplikasi yang mendukung dalam pembuatan media pembelajaran interaktif sebagai berikut. 


\subsection{Adobe Flash}

"Pertama kali flash dikembangkan oleh macromedia, kemudian diambil alih oleh adobe system. Pada Tahun 1996. Flash sangat dikenal dikarenakan dapat menambahkan media animasi dan interaksi melalui web.Flash tidak hanya digunakan dalam media web tetapi sekarang ini flash dapat digunakan melalui aplikasi dekstop. Format flash itu sendiri berupa swf, dan flash dapat dikembangkan dengan menjadi kompilasi format exe". Menurut Sunyoto[5].

\subsubsection{Action Script}

"bahasa standar yang digunakan oleh flash adalah action script. Dimana action script adalah kumpulankumpulan dari function, action, event handler, dan event. Action script mengalami perkembangan dari tahun ketahun dari versi 1, versi 2 dan versi 3. Dan pada kenyataaan nya action script versi 2 adalah bahasa standar yang sering digunakan dikarenakan lebih mudah dalam pembuatannya. Action script juga berkaitan erat dengan pengiolahan frame dan timeline. Dimana Kedua harus dioleh sedemikian rupa untuk menghasilkan sebuah animasi”.. Menurut Sunyoto [5]

\subsubsection{XML (eXtensible Markup Language)}

"XML memiliki singkatan dari eXtensible Markup Language XML bahasa xml ini sangat erat kaitanya dengan fungsi html didalam sebuah web, dimana memudahkan dalam melakukan transisi atau perubahan data, Misalkan setiap aplikasi akan menghasilkan suatu output yang berbeda-beda maka untuk menjadi media perantara bahasa xml yang paling mudah digunakan atau menjadi solusi dalam exporting data". Menurut Sunardi [6]. "Penggunaan XML untuk diintegrasikan sebagai database pada flash. Dahulunya flash hanya bisa digunakan sekedar membuat animasi, seiring perkembangannya (adobe flash), flash bisa diintegrasikan dengan XML untuk membuat sebuah program yang lebih dinamis dan dilengkapi akan fitur (Rich Multimedia Application). Program yang digunakan menggunakan database XML, sehingga program menjadi lebih dinamis".

\subsection{Model Pembelajaran}

Model pembelajaran [7] adalah perencanaan yang menghasilkan pola yang akan digunakan atau dipakai sebagai suatu panduan pembelajaran dalam melaksanakan kegiatan belajar mengajar dengan menggunakan metode pembelajaran tutorial, dan menentukan apa saja yang diperlukan dalam pembelajaran tersebut seperti video audio, gambar, komputer atau yang lainnya.

2.6. Strategi Pembelajaran

Strategi pembelajaran[8] adalah rencana tindakan (rangkaian kegiatan) termasuk penggunaan metode dan pemanfaatan berbagai sumber daya atau kekuatan dalam pembelajaran yang disusun untuk mencapai tujuan tertentu. Dalam hal ini adalah tujuan pembelajaran.

Strategi pembelajaran merupakan hal yang perlu di perhatikan oleh seorang instruktur, guru dalam proses pembelajaran. Paling tidak ada 3 jenis strategi yang berkaitan dengan pembelajaran, yakni:

(a) strategi pengorganisasian pembelajaran

(b) strategi penyampaian pembelajaran

(c) strategi pengelolaan pembelajaran.

\subsection{Simulasi.}

Simulasi[9] adalah sebuah replikasi atau visualisasi dari perilaku sebuah sistem, misalnya sebuah perencanaan pendidikan, yang berjalan pada kurun waktu yang tertentu. Jadi dapat dikatakan bahwa simulasi itu adalah sebuah model yang berisi seperangkat variabel yang menampilkan ciri utama dari sistem kehidupan yang sebenarnya. Simulasi memungkinkan keputusan-keputusan yang menentukan bagaimana ciri-ciri utama itu bisa dimodifikasi secara nyata. Prosedur yang harus ditempuh dalam penggunaan metode simulasi[10] adalah:

1) Menetapkan topik simulasi yang diarahkan oleh guru,

2) Menetapkan kelompok dan topik-topik yang akan dibahas,

3) Simulasi diawali dengan petunjuk dari guru tentang prosedur, teknik, dan peran yang dimainkan,

4) Proses pengamatan pelaksanaan simulasi dapat dilakukan dengan diskusi,

5) Mengadakan kesimpulan dan saran dari hasil kegiatan simulasi. 


\section{RESEARCH METHOD}

\subsection{Desain Penelitian}

Berikut desain penelitian yang dilakukan selama 1 tahun.

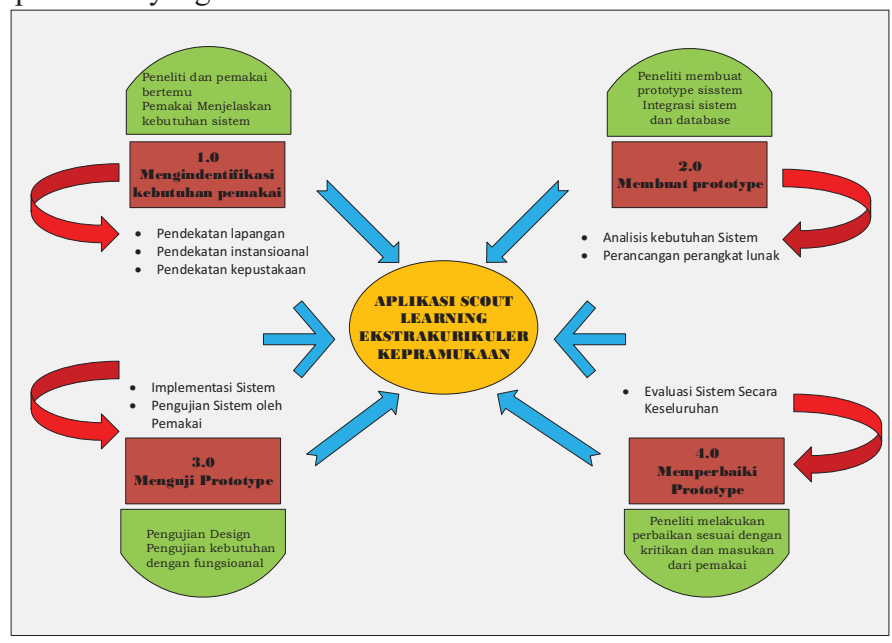

Gambar 3.1 Desain Penelitian

\subsection{Teknik Pengumpulan Data}

Adapun teknik yang digunakan sebagai berikut :

a) Wawancara dan dan angket.

Teknik wawancara melibatkan guru, guru Pembina kepramukaan, Siswa/Siswi SD sebagai sumber data yang diperlukan dikarenakan mereka terlibat secara langsung, disini kami sebagai peneliti menyediakan dan mengajukan pertanyaan secara tertulis dan lisan. Untuk wawancara secara langsung maka kami sediakan angket untuk beberapa pertanyaan yang ada mengenai kepramukaan disekolah tersebut termasuk permasalahan. Kemudian untuk alternative lain yaitu wawancara melalui via telephone dimaksudkan ketika hal penting terjadi, jika para narasumber tidak bisa melakukan wawancara secara langsung.

b) Observasi dan penelitian lapangan.

Observasi adalah pengamatan langsung kepada suatu obyek yang akan diteliti, sedangkan penelitian lapangan adalah usaha pengumpulan data dan informasi secara intensifdisertai analisa dan pengujian kembali atas semua yang telah dikumpulkan. Untuk observasi dan penelitian kelapangan sendiri diadakan di SD Negeri Cimahi Mandiri.

c) Penelitian Kepustakaan

Hal ini ditujukan untuk memperkuat data dalam membangun sebuah system dan landasan kegiatan yang ada mengenai kepramukaan di Sekolah Dasar.

\section{RESUlTS AND DiscuSSION}

\subsection{Penerapan Aplikasi}

a) Menu Intro

Pada saat aplikasi Scout Learningdijalankan, maka akan menampilkan tampilan pembuka, dan untuk masuk ke menu utama userharus mengklik tombol "Masuk". 
Andri Sahata Sitanggang

Pembuatan Scout Learning Berbasis..

b) Loading

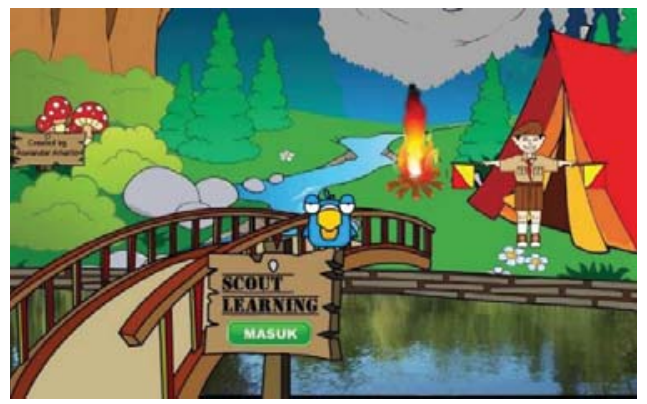

Gambar 4.1 Menu Intro

Tampilan loading ini menambah minat user untuk menunggu tampilan yang akan ditawarkan berikutnya. Terdapat materi tentang pengertian kepramukaan pada saat loading berlangsung.

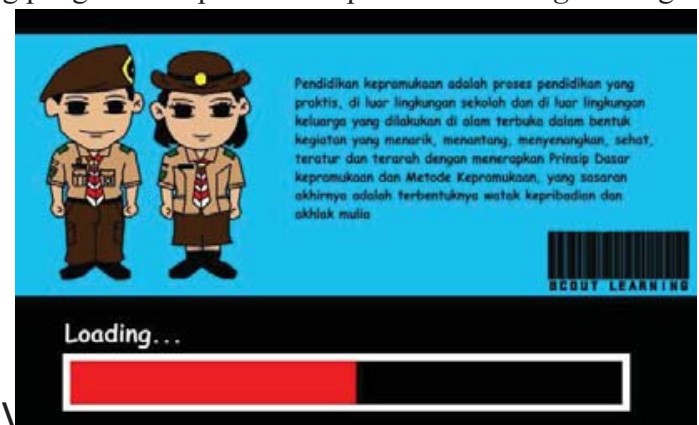

Gambar 4.2 Loading

c) Menu Utama

Pada menu ini terdapat pilihan menu materi yang diberikan yang terdiri dari menu materi pramuka, menu simulasi, menu istilah pramuka, menu peralatan pramuka dan menu quis pramuka.

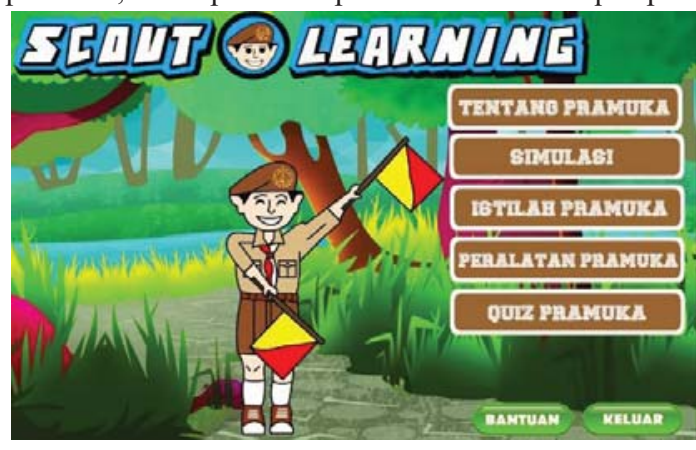

Gambar 4.3 Menu Utama

d) Menu Tentang Pramuka

Memberikan Intisari atau Materi Pembelajaran tentang pramuka dan disajikan dalam bentuk animasi buku. 


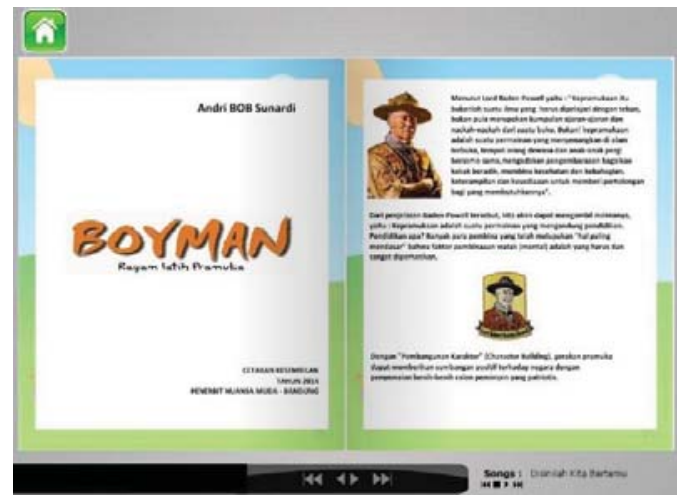

Gambar 4.4. Materi Pramuka

e) Menu Simulasi Sandi Semaphore

Pada menu ini menampilan simulasi sandi semaphore yang terdiri dari huruf, angka dan tanda lain. Terdapat pula latihan dasar dan latihan mahir.

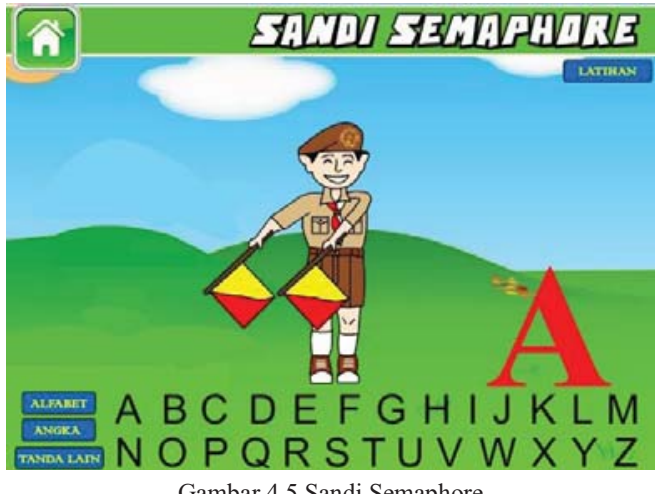

f) Menu Simulasi Sandi Morse

Gambar 4.5 Sandi Semaphore

Pada menu ini menampilan simulasi sandi morse yang terdiri dari huruf, angka dan tanda baca. Terdapat pula latihan dasar dan latihan mahir.

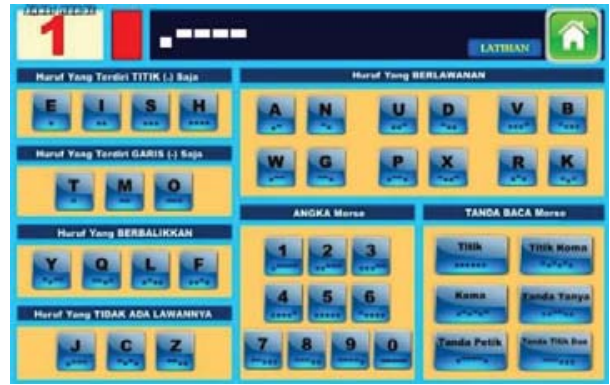

g) Menu Simulasi Simpul

Gambar 4.6 Sandi Morse

Pada menu ini menampilan simulasi simpul tali temali yang terdiri dari simpul pangkal, simpul tiang, simpul ujung tali, simpul mati, simpul hidup, simpul kembar, simpul erat, simpul anyam berganda, dan simpul anyam. 
Andri Sahata Sitanggang

Pembuatan Scout Learning Berbasis..

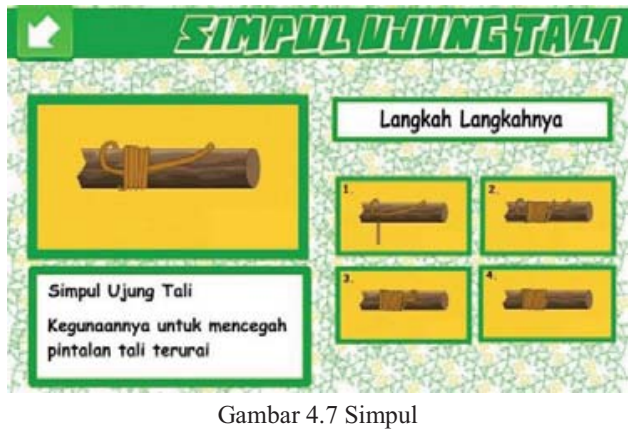

h) Menu Tepuk Pramuka

Pada menu ini menampikan simulasi tepuk tangan yang dipadukan dari suara tepuk tangan dengan animasi tepuk tangan

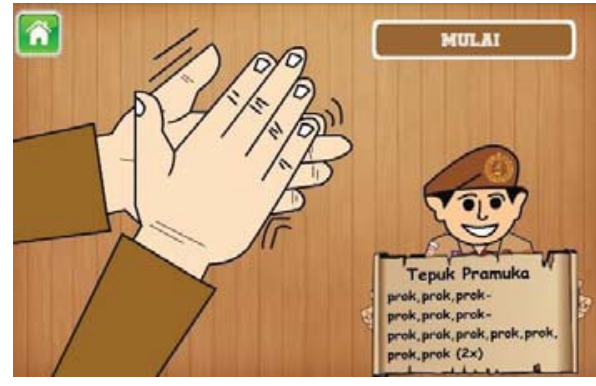

Gambar 4.8 Tepuk Pramuka

i) Menu Istilah Pramuka

Pada menu ini menampilkan kumpulan istilah pramuka dari huruf A-Z lengkap dengan penjelasan setiap istilah. User bisa melakukan search untuk mencari istilah pramuka

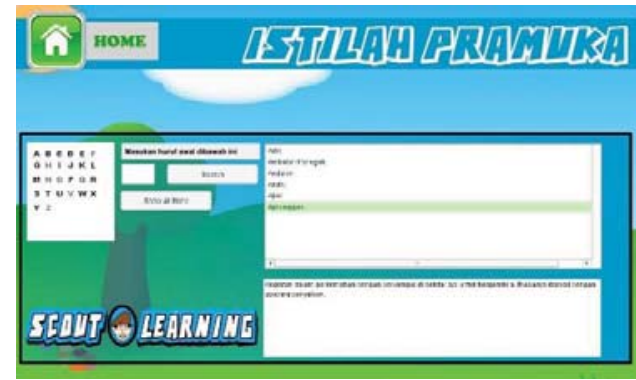

Gambar 4.9 Istilah Pramuka

j) Menu Peralatan Seragam Pramuka Putra

Pada menu ini menampilkan seragam pramuka putra dan user bisa menggunakan fitur drag and drop. Terdapat pula deskripsi dari seragam yang digunakan 


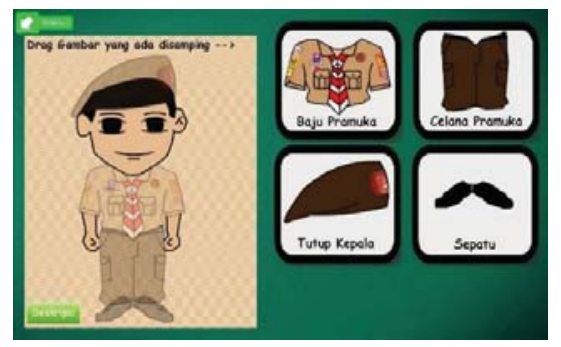

Gambar 4.10 Seragam Pramuka Putra

k) Menu Peralatan Seragam Pramuka Putri

Pada menu ini menampilkan seragam pramuka putri dan user bisa menggunakan fitur drag and drop. Terdapat pula deskripsi dari seragam yang digunakan.

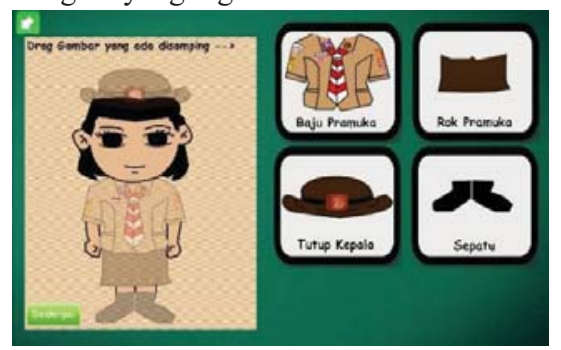

Gambar 4.11 Seragam Pramuka Putri

1) Menu Peralatan atribut pramuka

Pada menu ini menampilkan atribut pramuka pada seragam yang digunakan. Lengkap dengan letak posisi atribut tersebut.

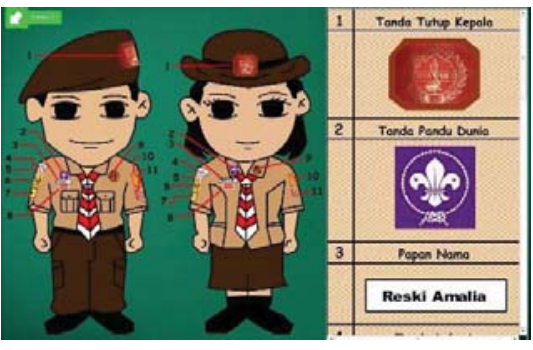

Gambar 4.12 Atribut Pramuka

m) Menu Perlengkapan Pramuka

Pada menu ini menampilkan perlengkapan pramuka yang sering digunakan.

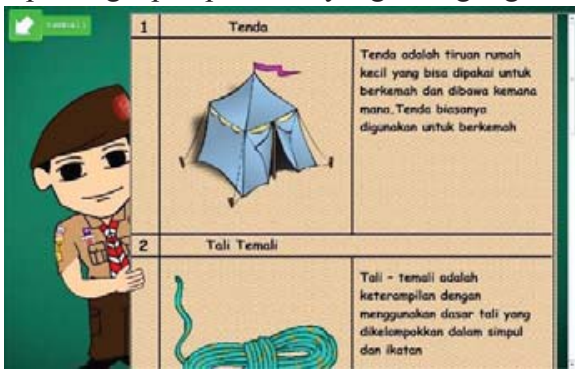

Gambar 4.13 Perlengkapan Pramuka 
n) Menu Kuis Pramuka

Pada menu ini menampilkan quis pramuka yaitu berupa pilihan ganda tentang materi pramuka. Terdapat nilai di akhir quis

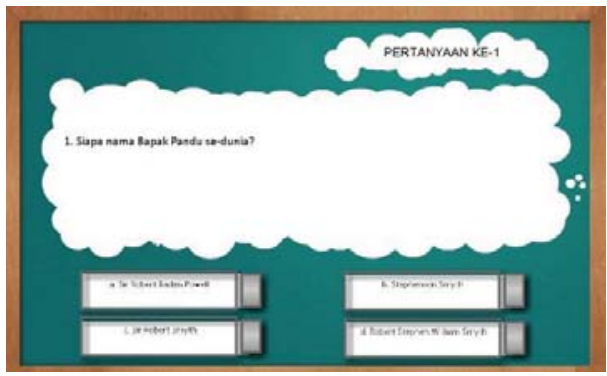

Gambar 4.14 Kuis Pramuka

\subsection{Pengujian terhadap aplikasi}

Pengujuan yang dilakukan melalui 2 tahapan pengujian alfa dan pengujian beta.

1. Pengujian Alfa

Pengujian aplikasi ini menggunakan metode Blackbox yang digunakan untuk menguji dari aplikasi yang dirancang. Dengan menggunakan metoda pengujian ini perekayasaan sistem dapat dilakukan test case yaitu:

a) Menggunakan keputusan logis pada sisi true dan false

b) Memberi jaminan bahwa semua jalur independen pada suatu modul telah digunakan paling sedikit satu kali.

TABel 4.1 TABel Pengujian

\begin{tabular}{|c|c|c|c|c|}
\hline No & Fungsi Yang Diuji & Cara Pengujian & Hasil Yang Diharapkan & Hasil \\
\hline 1 & Fungsi menu pembuka & Membuka aplikasi & $\begin{array}{l}\text { Aplikasi bisa terbuka dan } \\
\text { menampilkan menu pembuka }\end{array}$ & OK \\
\hline 2 & $\begin{array}{l}\text { Fungsi menu materi } \\
\text { pramuka }\end{array}$ & $\begin{array}{l}\text { Pilih menu materi } \\
\text { pramuka pada menu } \\
\text { utama }\end{array}$ & $\begin{array}{l}\text { Aplikasi menampilkan materi } \\
\text { pramuka }\end{array}$ & OK \\
\hline 3 & Fungsi menu simulasi & $\begin{array}{l}\text { Pilih menu simulasi pada } \\
\text { menu utama }\end{array}$ & $\begin{array}{l}\text { Aplikasi menampilkan pilihan } \\
\text { menu simulasi yaitu sandi } \\
\text { semaphore,sandi morse dan simpul }\end{array}$ & OK \\
\hline 4 & $\begin{array}{l}\text { Fungsi menu sandi } \\
\text { semaphore }\end{array}$ & $\begin{array}{l}\text { Pilih menu simulasi pada } \\
\text { menu utama kemudian } \\
\text { pilih menu sandi } \\
\text { semaphore }\end{array}$ & $\begin{array}{l}\text { Aplikasi menampilkan materi } \\
\text { sandi semaphore }\end{array}$ & OK \\
\hline 5 & $\begin{array}{l}\text { Fungsi latihan sandi } \\
\text { semaphore }\end{array}$ & $\begin{array}{l}\text { Pilih menu simulasi pada } \\
\text { menu utama lalu pilih } \\
\text { menu sandi semaphore } \\
\text { kemudian pilih menu } \\
\text { latihan }\end{array}$ & $\begin{array}{l}\text { Aplikasi menampilkan kumpulan } \\
\text { soal sandi semaphore dan } \text { user bisa } \\
\text { memilih jawabannya }\end{array}$ & OK \\
\hline 6 & $\begin{array}{l}\text { Fungsi menu sandi } \\
\text { morse }\end{array}$ & $\begin{array}{l}\text { Pilih menu simulasi pada } \\
\text { menu utama kemudian } \\
\text { pilih menu sandi morse }\end{array}$ & $\begin{array}{l}\text { Aplikasi menampilkan materi } \\
\text { sandi morse }\end{array}$ & $\mathrm{OK}$ \\
\hline 7 & $\begin{array}{l}\text { Fungsi latihan sandi } \\
\text { morse }\end{array}$ & $\begin{array}{l}\text { Pilih menu simulasi pada } \\
\text { menu utama lalu pilih } \\
\text { menu sandi morse } \\
\text { kemudian pilih menu } \\
\text { latihan }\end{array}$ & $\begin{array}{l}\text { Aplikasi menampilkan kumpulan } \\
\text { soal sandi morse dan user bisa } \\
\text { memilih jawabannya }\end{array}$ & OK \\
\hline 8 & Fungsi menu simpul & $\begin{array}{l}\text { Pilih menu simulasi pada } \\
\text { menu utama kemudian }\end{array}$ & $\begin{array}{l}\text { Aplikasi menampilkan materi } \\
\text { simpul }\end{array}$ & OK \\
\hline
\end{tabular}




\begin{tabular}{|c|c|c|c|c|}
\hline No & Fungsi Yang Diuji & Cara Pengujian & Hasil Yang Diharapkan & Hasil \\
\hline & & $\begin{array}{l}\text { pilih menu simpul (Tali- } \\
\text { Temali) }\end{array}$ & & \\
\hline 9 & $\begin{array}{l}\text { Fungsi menu istilah } \\
\text { pramuka }\end{array}$ & $\begin{array}{l}\text { Pilih menu istilah } \\
\text { pramuka pada menu } \\
\text { utama }\end{array}$ & $\begin{array}{l}\text { Aplikasi menampilkan materi } \\
\text { istilah pramuka }\end{array}$ & $\mathrm{OK}$ \\
\hline 10 & $\begin{array}{l}\text { Fungsi cari istilah } \\
\text { pramuka }\end{array}$ & $\begin{array}{l}\text { Pilih menu istilah } \\
\text { pramuka pada menu } \\
\text { utama kemudian cari } \\
\text { istilah berdasarkan huruf } \\
\text { awalan }\end{array}$ & $\begin{array}{l}\text { Aplikasi menampilkan istilah } \\
\text { pramuka berdasarkan huruf awalan } \\
\text { yang dicari }\end{array}$ & $\mathrm{OK}$ \\
\hline 11 & $\begin{array}{l}\text { Fungsi peralatan } \\
\text { pramuka }\end{array}$ & $\begin{array}{l}\text { Pilih menu peralatan } \\
\text { pramuka pada menu } \\
\text { utama }\end{array}$ & $\begin{array}{l}\text { Aplikasi menampilkan pilihan } \\
\text { menu peralatan pramuka yaitu } \\
\text { seragam pramuka putra, seragam } \\
\text { pramuka putri, atribut pramuka } \\
\text { dan perlengkapan pramuka. }\end{array}$ & $\mathrm{OK}$ \\
\hline 12 & $\begin{array}{l}\text { Fungsi menu seragam } \\
\text { pramuka putra }\end{array}$ & $\begin{array}{l}\text { Pilih menu peralatan } \\
\text { pramuka pada menu } \\
\text { utama kemudian pilih } \\
\text { menu seragam pramuka } \\
\text { putra }\end{array}$ & $\begin{array}{l}\text { Aplikasi menampilkan seragam } \\
\text { pramuka putra beserta } \\
\text { deskripsinya }\end{array}$ & OK \\
\hline 13 & $\begin{array}{l}\text { Fungsi menu seragam } \\
\text { pramuka putri }\end{array}$ & $\begin{array}{l}\text { Pilih menu peralatan } \\
\text { pramuka pada menu } \\
\text { utama kemudian pilih } \\
\text { menu seragam pramuka } \\
\text { putri }\end{array}$ & $\begin{array}{l}\text { Aplikasi menampilkan seragam } \\
\text { pramuka putri beserta deskripsinya }\end{array}$ & $\mathrm{OK}$ \\
\hline 14 & $\begin{array}{l}\text { Fungsi menu atribut } \\
\text { pramuka }\end{array}$ & $\begin{array}{l}\text { Pilih menu peralatan } \\
\text { pramuka pada menu } \\
\text { utama kemudian pilih } \\
\text { menu atribut pramuka }\end{array}$ & $\begin{array}{l}\text { Aplikasi menampilkan materi } \\
\text { atribut pramuka }\end{array}$ & $\mathrm{OK}$ \\
\hline 15 & $\begin{array}{l}\text { Fungsi menu } \\
\text { perlengkapan pramuka }\end{array}$ & $\begin{array}{l}\text { Pilih menu peralatan } \\
\text { pramuka pada menu } \\
\text { utama kemudian pilih } \\
\text { menu perlengkapan } \\
\text { pramuka }\end{array}$ & $\begin{array}{l}\text { Aplikasi menampilkan materi } \\
\text { perlengkapan pramuka }\end{array}$ & $\mathrm{OK}$ \\
\hline 16 & $\begin{array}{l}\text { Fungsi drag and drop } \\
\text { pada menu seragam } \\
\text { pramuka putra }\end{array}$ & $\begin{array}{l}\text { Pilih menu peralatan } \\
\text { pramuka pada menu } \\
\text { utama lalu pilih menu } \\
\text { seragam pramuka putra } \\
\text { kemudian drag seragam } \\
\text { pramuka }\end{array}$ & $\begin{array}{l}\text { Seragam pramuka bisa di drag ke } \\
\text { target }\end{array}$ & $\mathrm{OK}$ \\
\hline 17 & $\begin{array}{l}\text { Fungsi drag and drop } \\
\text { pada menu seragam } \\
\text { pramuka putri }\end{array}$ & $\begin{array}{l}\text { Pilih menu peralatan } \\
\text { pramuka pada menu } \\
\text { utama lalu pilih menu } \\
\text { seragam pramuka putri } \\
\text { kemudian drag seragam } \\
\text { pramuka }\end{array}$ & $\begin{array}{l}\text { Seragam pramuka bisa di drag ke } \\
\text { target }\end{array}$ & $\mathrm{OK}$ \\
\hline 18 & Fungsi kuis pramuka & $\begin{array}{l}\text { Pilih menu kuis pramuka } \\
\text { pada menu utama }\end{array}$ & $\begin{array}{l}\text { Aplikasi menampilkan kuis } \\
\text { pramuka }\end{array}$ & $\mathrm{OK}$ \\
\hline 19 & $\begin{array}{l}\text { Fungsi input nama pada } \\
\text { kuis pramuka }\end{array}$ & $\begin{array}{l}\text { Pilih menu kuis pramuka } \\
\text { pada menu utama } \\
\text { kemudian menginputkan } \\
\text { nama }\end{array}$ & $\begin{array}{l}\text { Aplikasi menampilkan nama pada } \\
\text { saat mengerjakan kuis }\end{array}$ & OK \\
\hline 20 & $\begin{array}{l}\text { Fungsi score pada kuis } \\
\text { pramuka }\end{array}$ & $\begin{array}{l}\text { Pilih menu kuis pramuka } \\
\text { pada menu utama lalu } \\
\text { menginputkan nama } \\
\text { kemudian menjawab soal }\end{array}$ & $\begin{array}{l}\text { Aplikasi menampilkan hasil akhir } \\
\text { atau score pada akhir kuis. }\end{array}$ & $\mathrm{OK}$ \\
\hline
\end{tabular}


2. Pengujian Beta

Pengujian beta merupakan pengujian yang dilakukan secara objektif. Pengujian beta yang dilakukan untuk mengenai kepuasan user dengan kandungan point syarat user friendly untuk selanjutnya dibagikan kepada pengguna. Pengujian ini dilakukan dengan memberikan kuesioner kepada 10 siswa pramuka SD Mandiri dari 10 pertanyaan yang diberikan. Point penilaian dari aspek kuesioner yang dapat dilihat pada tabel berikut :

\begin{tabular}{|c|c|}
\hline Jawaban & Point Penilaian \\
\hline Sangat Setuju & 4 \\
\hline Setuju & 3 \\
\hline Tidak Setuju & 2 \\
\hline Sangat Tidak Setuju & 1 \\
\hline
\end{tabular}

Berikut ini adalah hasil perhitungan dari masing-masing jawaban yang sudah dihitung nilainya dengan menggunakan skala Likert.

TABEL 0.3 KUESIONER NOMOR 1

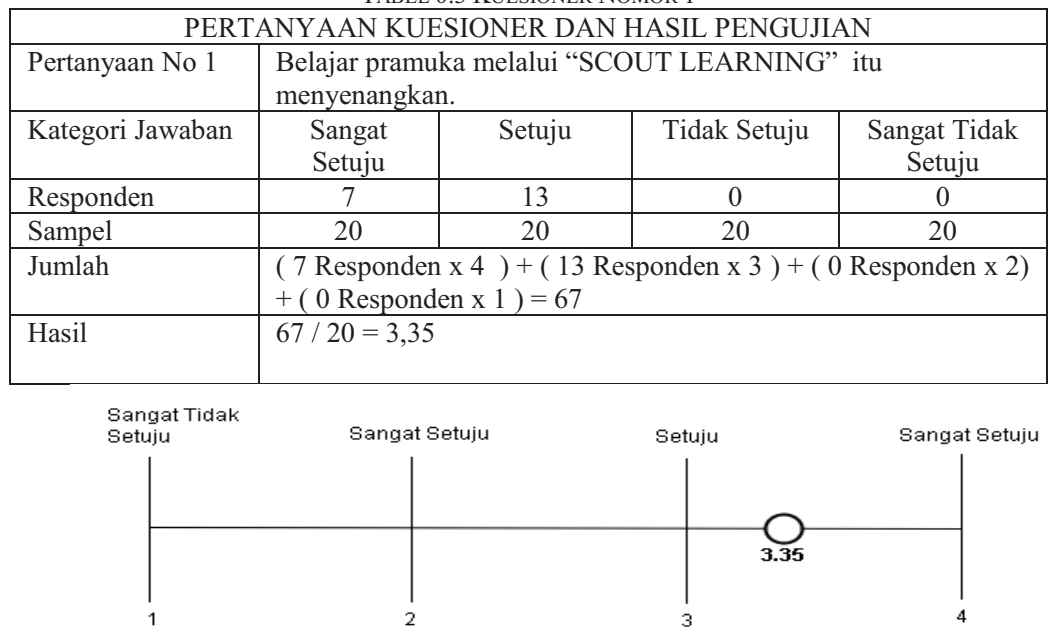

Gambar 4.16 Penilaian

Maka hasil dari kusioner 2 sampai dengan kusioner 10 diperoleh nilai berikut : TABEL 4.4 HASIL PENILAIAN

\begin{tabular}{|l|l|}
\hline Nama kusioner & Jumlah Nilai \\
\hline Kusioner 2 & $\mathbf{3 . 2}$ \\
\hline Kusioner 3 & $\mathbf{3 . 3}$ \\
\hline Kusioner 4 & $\mathbf{3 . 3}$ \\
\hline Kusioner 5 & $\mathbf{3 . 3 5}$ \\
\hline Kusioner 6 & $\mathbf{3 . 4}$ \\
\hline Kusioner 7 & $\mathbf{3 . 1}$ \\
\hline Kusioner 8 & $\mathbf{3 . 5 5}$ \\
\hline Kusioner 9 & $\mathbf{3 . 5}$ \\
\hline Kusioner 10 & $\mathbf{3 . 3 5}$ \\
\hline Rata-rata & $\mathbf{3 . 0 5}$ \\
\hline
\end{tabular}

Berdasarkan hasil penilaian tersebut maka dapat disimpulkan bahwa para siswa setuju dengan adanya aplikasi pembelajaran kepramukaan yang dibuat.

o) Kebutuhan Perangkat Keras Dan Lunak Dalam membangun aplikasi.

1. Kebutuhan Perangkat Lunak 
2. Kebutuhan perangkat Keras

\begin{tabular}{|c|c|c|}
\multicolumn{3}{c}{ TABEL 4.5 IMPLEMENTASI PERANGKAT LUNAK } \\
\hline No & Software & Software yang digunakan \\
\hline 1 & Operating system & Windows 7 \\
\hline 2 & Media & Adobe flash player \\
\hline
\end{tabular}

\begin{tabular}{|l|l|l|}
\multicolumn{3}{|c|}{ TABEL 4.6 IMPELEMENTASI PERANGKAT KERAS } \\
\hline No & Hardware & Hardware Yang dibangun \\
\hline 1 & Processor & Processor intel core 2 duo \\
\hline 2 & Hardisk & Hardisk 342 GB \\
\hline 3 & Memory/RAM & RAM 2 GB \\
\hline 4 & Input/output & $\begin{array}{l}\text { Mouse, Keyboard, Monitor (resolusi 1024x768) } \\
\text { sebagai peralatan antarmuka }\end{array}$ \\
\hline
\end{tabular}

\section{KESIMPULAN}

1. Aplikasi Scout Learning dapat membantu siswa dalam mempelajari materi pramuka terdiri dari simulasi, materi kepramukaan, istilah-istilah pramuka, peralatan pramuka dan kuis pramuka

2. Aplikasi Scout Learning dapat membantu siswa dalam mempelajari penggunaan alat pramuka dengan simulasi yang interaktif.

3. Aplikasi Scout Learning dapat membangkitkan minat belajar siswa dalam mempelajari pramuka.

4. Berdasarkan hasil pengujian, maka dapat disimpulkan bahwa aplikasi Scout Learning ini dapat membantu siswa mempelajari pramuka dengan tampilan yang menarik dan mudah untuk digunakan..

\section{UCAPAN TERIMAKASIH}

Mengucapkan rasa terimakasih sebesar-besarnya Kepada DIPA Direktorat Penelitian dan Pengabdian kepada Masyarakat Kementerian Pendidikan dan Kebudayaan sesuai dengan Surat Perjanjian Penugasan Pelaksanaan Program Pengabdian Kepada Masyarakat Direktorat Riset Dan Pengabdian Kepada Masyarakat Tahun Anggaran 2017 Nomor : 060B/KP/PPM/Dir-LPPM/UNIKOM/VI/2017 yang sudah berkenan memberikan dana untuk kegiatan penelitian ini

\section{REFERENCES}

[1]Dahlan, R. A. 2008. Pedoman Materi : Kursus Pembina Pramuka Mahir Tingkat Dasar. Lemdika Gerakan Pramuka. Purwokerto. [2]Darma, J. S., \& Ananda, S. 2009. Buku Pintar Menguasai Multimedia.TransMedia. Jakarta Selatan.

[3]Hofstetter, F. T. 2001. Multimedia Literacy. Pressman. New York.

[4]http://www.m-edukasi.web.id/ Unsur Multimedia Dalam Pembelajaran/ 4 April 2014 Shalahuddin, R. M. 2013. Rekayasa Perangkat Lunak.Informatika. Yogyakarta.

[5]https://www.academia.edu/Storyboard sketsa gambar yang disusun berurutan sesuai dengan naskah/ 19 Juni 2014

[6]MADCOMS. 2008. Adobe Flash CS3 Professional. Andi. Yogyakarta.

[7]Trianto. (2011).Model-model pembelajaran inovatif berorientasi konstruktivitis. Jakarta:Prestasi Pustaka.

[8]Sholahuddin. 2010. Strategi Pembelajaran Aktif Learning. Online diakses http://sholahuddin.edublogs.org/2010/05/03/strategipembelajaran-active-learning-2//2012/05/11/10:2.

[9] Syaefudin, Udin., Syamsuddin, Abin. (2005) Perencanaan Pendidikan Pendekatan Komprehensif. Bandung: PT Remaja Rosdakarya

[10] Anitah, Sri, W, dkk. (2007) Strategi Pembelajaran di SD. Jakarta: Universitas Terbuka 
